This is the peer reviewed version of the following article: Putniňš, TJ, Sauka, A. Why does entrepreneurial orientation affect company performance? Strategic Entrepreneurship Journal. 2020; 14: 711- 735, which has been published in final form at https://doi.org/10.1002/sej.1325. This article may be used for non-commercial purposes in accordance with Wiley Terms and Conditions for Self-Archiving.

\title{
Why does entrepreneurial orientation affect company performance? ${ }^{1}$
}

\author{
Tālis J. Putniņš \\ University of Technology Sydney \\ Stockholm School of Economics in Riga \\ Arnis Sauka \\ Stockholm School of Economics in Riga
}

Strategic Entrepreneurship Journal (forthcoming)

\begin{abstract}
Research summary:

To better understand why entrepreneurial orientation (EO) is positively associated with company performance, we propose and test a reconceptualization of how the components of EO (risk taking, innovativeness, proactiveness) combine in driving performance. Drawing on financial economics theory, our conceptualization highlights that all three components positively contribute to performance, but in different ways. Risk taking has a direct positive relationship with performance, which can be understood through the risk-return tradeoff that is central in financial economics theory. The relationship between risk taking and performance is conditional on the level of innovativeness and thus innovativeness contributes to performance through its effect on the type of risk taking. Proactiveness contributes to performance through its positive effect on the level of risk taking.
\end{abstract}

\section{Managerial summary:}

This study analyzes three key drivers of company performance: risk taking, innovativeness, and proactiveness. We show that constructive risk taking is the central driver of company performance, mirroring the principle of risk and return in financial investment settings. Risk taking that is associated with innovation has a particularly strong positive relationship with performance, consistent with innovation being a driver of growth and profitability. More proactive firms tend to take on more risk and thus also perform better than less proactive firms.

Keywords: entrepreneurial orientation, performance, conceptualization, risk taking, innovativeness, proactiveness

JEL classification: L25, L26, M21

\footnotetext{
${ }^{1}$ Corresponding author: Talis J. Putnins, UTS Business School, PO Box 123 Broadway, Sydney NSW 2007, Australia. Phone: +612 95143088. Email: talis.putnins@uts.edu.au

The Online Appendix that accompanies this paper can be obtained here https://bit.ly/2VP5oqP

We thank two anonymous referees, the editor (Tom Lumpkin), Per Davidsson, Tomasz Mickiewicz, Ute Stephan, Laszlo Szerb, Johan Wiklund, and participants at the $32^{\text {nd }}$ Annual Babson College Entrepreneurship Research Conference, the University of Technology Sydney, and the Stockholm School of Economics in Riga for helpful comments. We also than Anders Paalzow and the Stockholm School of Economics in Riga for funding the data collection.
} 


\section{Introduction}

Entrepreneurial orientation (EO), which reflects inclinations of key players within a firm to take calculated risks, innovate, and pursue proactive behaviors (e.g., Miller, 1983; Lumpkin and Dess, 1996), is among the most validated and widely used constructs in the strategic entrepreneurship literature (e.g., Anderson et al., 2015; Runyan et al., 2012). Our understanding of EO, its relationship with performance, the factors that influence this relationship, and what constitutes EO, is rich, yet is constantly evolving. For example, Linton (2016) notes that in the period up to the end of 2010, 256 scholarly articles refer to EO (Covin and Lumpkin, 2011). Using the same search criteria, in the subsequent few years through to mid-2015, a further 360 new research articles refer to EO.

The relationship between EO and firm performance has been widely studied (e.g., Rauch et al., 2009; Miller, 2011; Gupta and Wales, 2017). Many studies find that EO contributes to performance (e.g., Saeed et al., 2014; Rauch et al., 2009). This result has been found in a large number of different national contexts (Semrau et al., 2016) including countries other than the US and Western Europe, and using different operational definitions of EO and firm performance (Wales et al., 2013; Rauch et al., 2009). There are, however, studies that do not find a positive relationship between EO and performance, suggesting the EO-performance relationship may be more complex than a universal linear relationship (e.g., Andersen, 2010; Hughes and Morgan, 2007).

Despite the substantial research effort directed to EO, there are still important issues about EO and its relationship with performance that are not well understood. There is a lively debate in the literature about the conceptualization of EO-whether it is a unidimensional construct in which the elements of EO (risk taking, innovativeness, and proactiveness) together reflect a strategic orientation towards entrepreneurship, or whether it is a multidimensional construct in which each of the dimensions can play a unique role in driving firm performance. 
Studies that adopt the multidimensional view tend to focus on the effects of one or two dimensions of EO (e.g., Lumpkin and Dess, 1996; Walls and Dyer, 1996), independent effects of various EO dimensions on EO performance (e.g., George and Marino, 2011; Kreiser et al., 2013), the unique effects of the dimensions in a particular industry (e.g., Hughes and Morgan, 2007), and nonlinearity between each of the dimensions and performance (e.g., Kreiser et al., 2013). Surprisingly little is known about how the dimensions of EO combine and interact in determining performance. For example, are risk taking, innovativeness, and proactiveness simply substitutes such that a lack of one can be compensated by more of another? Or do they interact in such a way that a particular combination of the three contributes to high performance? Do some dimensions have a direct impact on performance, while others affect performance through their effects on the direct drivers?

Our paper aims to address the above questions. We analyze the interrelations between the dimensions of EO and develop a model of how they interact in determining performance. We identify which dimensions are direct drivers of performance, and which dimensions are related to performance through mediating and/or moderating relationships with other dimensions of EO. Thus, our approach is inherently a configurational one, in the spirit of much of the recent EO literature. However, it differs from the existing literature in that it looks for a configurational model internally within the dimensions of EO rather than between EO and external factors. Following the call to return to the conceptual discussion of EO in order to further advance the field (Covin and Lumpkin, 2011), we propose and test a reconceptualization of the EO-performance relationship, focusing on the unique roles and interactions of risk taking, innovativeness, and proactiveness. Our conceptualization draws on financial economics theory, in particular how and why risk and uncertainty are related to investment returns.

We propose that risk taking has a direct positive relationship with performance, which can be understood through the risk-return tradeoff that is central in financial economics theory. The basic 
intuition is that because less risk or less uncertainty is generally preferred to more (all else equal), entrepreneurs will usually only take on riskier or more uncertain ventures/strategies if they are accompanied by better expected performance.

We further propose that innovativeness positively contributes to performance by impacting the types of risk taken within the firm (moderating the risk taking-performance relationship)_risk taking in highly innovative firms is associated with better performance than risk taking in less innovative contexts.

Finally, we propose that proactiveness has an indirect positive relationship with performance through its positive effect on the level of risk taking (a mediated relationship). Being the first to exploit opportunities and acting as a market leader in anticipating future demand involves taking risks. We find empirical support for our re-conceptualization using a sample of 1,020 firms.

The contribution of this paper is a nuanced model of how and why EO contributes to performance. The key insights are that risk taking has a direct, positive effect on performance, which is conditional on the level of innovativeness, while proactiveness affects performance through its effect on the level of risk taking. Therefore, each dimension of EO has a positive effect on performance, but for different reasons. Our findings do not negate previous work that adopts the unidimensional view. Rather, as pointed out by Kreiser et al. (2013), EO as a unidimensional concept has tremendous predictive validity with respect to performance, while disaggregated dimensions of EO (as in this paper) have a great deal of explanatory power in understanding what drives the EOperformance relationship.

The next section describes the theoretical framework, including a new conceptualization of how the dimensions of EO interact in driving performance. This new conceptualization is the basis for our empirical tests in Sections 3 and 4. In Section 5 we discuss implications of our findings and point out promising areas for future research. Our conclusions are summarized in Section 6. 


\section{Theoretical framework}

First we review existing conceptualizations of EO and its dimensions, paying attention to the individual roles of each of the dimensions. We then present a new conceptualization of the unique roles and interrelations between the dimensions of EO in how they affect performance.

\subsection{Existing literature}

The literature on EO is vast and continues to expand at a rapid pace. The literature has grown in its coverage of nations, with data on EO having been collected in at least 41 nations (Saeed et al., 2014). It has also grown in its coverage of different types of firms/organizations (e.g., Kraus, 2013; Tajjedini et al., 2013) and in connecting EO to a broader range of outcomes (e.g., Mickiewitz et al., 2016; Dada and Watson, 2013). Yet, despite the growth in the literature, EO research remains phenomena focused, rather than theory based, leading several scholars to call for a return to a conceptual discussion of EO in order to advance the field (e.g., Covin and Lumpkin, 2011).

There are a number of thorough reviews of the EO literature. These include reviews on the EO-performance relationship and the conceptualization of EO. ${ }^{2}$ Other, more specific reviews deal with variables that moderate the EO-performance relationship (Engelen et al., 2014), environmental, cultural, and macroeconomic contingencies that affect the EO-performance relationship (Gupta and Batra, 2016; Saeed et al., 2014), promising theoretical areas of EO research (Wales, 2016), and how the EO-performance relationship varies across different contexts (Semrau et al., 2016).

As one of the contributions of this paper, we also conduct a systematic review of specific aspects of the EO-performance literature tailored to addressing the question of "why does entrepreneurial orientation affect firm performance?" In total, we reviewed 54 systematically selected

\footnotetext{
2 See Gupta and Wales (2017), Wales (2016), Anderson et al. (2015), Covin and Miller (2014), Wales et al. (2013), Covin and Wales (2012), Covin and Lumpkin (2011), Miller (2011), Edmond and Wiklund (2010), Rauch et al. (2009), Rauch et al. (2004), and Zahra et al. (1999).
} 
empirical articles addressing the EO-performance relationship. ${ }^{3}$ The Online Appendix that accompanies this paper has details of the approach used in the review, tables summarizing the papers, and discussions of various issues in the literature. ${ }^{4}$ Below we summarize the key insights.

The first of the issues covered in our review is the sign and significance of the EOperformance relationship. The majority of studies find a statistically significant, positive relationship between EO and firm performance in a variety of contexts, using different measures of EO and performance (e.g., Saeed et al., 2014; Rauch et al., 2009; Semrau et al., 2016). A smaller number of studies do not find a significant relationship or even find a negative one (these are listed in Table A.3 of the Online Appendix). Many of the studies in this latter group suggest that the dimensions of EO might play unique roles and not all dimensions necessarily have a direct, positive relationship with performance. They call for a deeper understanding of the unique roles of the various dimensions and how these dimensions interact in driving firm performance.

The second issue is that of potential nonlinearity between EO and performance. The evidence on this issue is mixed. For instance, Tang et al. (2008) and several subsequent studies argue that firm performance may have an inverse $\mathrm{U}$ shaped relationship with EO. The evidence of nonlinearity is usually in the form of a significant quadratic term in a regression. Several other studies do not find evidence of nonlinearity (e.g., Gupta and Batra, 2016; Schepers et al., 2014; Lomberg et al., 2017).

\footnotetext{
${ }^{3}$ The 54 reviewed empirical studies are: Anderson and Eshima (2013); Becherer and Maurer (1997); Boso et al. (2013); Brouthers et al. (2014); Casillas and Moreno (2010); Chaston and Sadler-Smith (2012); Chirico et al. (2011); Covin et al. (2006); De Clercq et al. (2010); Deligianni et al. (2016); Engelen et al. (2015); Engelen et al. (2014); Gupta and Batra (2016); Hughes and Morgan (2007); Jiang et al. (2016); Keh et al. (2007); Kollmann and Stöckmann (2012); Lechner and Gudmundsson (2014); Li et al. (2009); Linton and Kask (2017); Lisboa et al. (2016); Lisboa et al. (2011); Lomberg et al. (2017); Lumpkin and Dess (2001); Martin and Javalgi (2016); McGee and Peterson (2017); Messersmith and Wales (2013); Miller and Breton-Miller (2011); Moreno and Casillas (2008); Naldi et al. (2007); Núñez-Pomar et al. (2016); Poon et al. (2006); Rauch et al. (2009); Real et al. (2014); Rigtering et al. (2017); Schepers et al. (2014); Semrau et al. (2016); Soininen et al. (2012); Stam and Elfring (2008); Stenholm et al. (2016); Su et al. (2015); Su et al. (2011); Tang et al. (2008); Tang and Tang (2012); Van Doorn et al. (2013); Vega-Vázquez et al. (2016); Wales et al. (2013a); Walter et al. (2006); Wang (2008); Wang et al. (2017); Wiklund and Shepherd (2005); Wiklund and Shepherd (2003); Wiklund (1999); and Zhao et al. (2009).

${ }^{4}$ The Online Appendix that accompanies this paper can be obtained here https://bit.ly/2VP5oqP
} 
The third issue is the theoretical perspectives that are used to explain how or why EO impacts firm performance. The literature has drawn on many theoretical perspectives including the resourcebased view, dynamic capability perspective, institutional theory, institutional logics, network theory, learning theory, agency theory, and several others. One grouping of the theoretical perspectives is into the universalistic view (which implies the EO-performance relationship is universal), versus the contingency fit view (which postulates that EO has to be aligned with the context to lead to increased performance). The contingency view, which was shaped by Covin and Slevin (1991) and Lumpkin and Dess (1996) among many others, has led to configurational models that combine elements of strategy with a variety of environmental and contextual considerations.

Despite recognizing the importance of contingencies and contextual factors, a consensus is yet to emerge about which are the key external or internal factors that moderate or mediate the EOperformance relationship. Many studies examine environmental contingencies. ${ }^{5}$ In contrast, far less is known about the influence of internal factors (e.g., Rauch et al., 2009; Wales et al., 2013). This is a gap the present paper seeks to fill by examining interrelations between the dimensions of EO and how a particular dimension might serve as a mediator or moderator of another dimension's effect on performance. In a sense, our approach is inherently a configurational/contingency approach, but looking for configurations within the components of EO rather than with external factors.

The fourth issue is the unique roles of the dimensions of EO. Of the 54 EO-performance studies that we reviewed, the 14 that disaggregate the components of EO and examine individual roles or interactions of the dimensions are summarized in Table A.2 of the Online Appendix. These studies use various conceptual frameworks and typically pay attention to only one or two dimensions, highlighting their "leading" role in shaping the EO-performance relation. For instance, some studies highlight innovativeness (e.g., Hughes and Morgan, 2007; Rauch et al., 2009; Casillas and Moreno,

\footnotetext{
${ }^{5}$ For example, Rigtering et al. (2017), Núñez-Pomar et al. (2016), Rauch et al. (2009), Engelen et al. (2015), Covin et al. (2006), Rosenbusch et al. (2013), Covin and Lumpkin (2011), and Lomberg et al. (2017).
} 
2010; Núñez-Pomar et al., 2016; Rigtering et al., 2017), risk taking (e.g., Naldi et al., 2007; Soininen et al., 2012), proactiveness (Hughes and Morgan, 2007; Lumpkin and Dess, 2001; Casillas and Moreno, 2010), and competitive aggressiveness (Lumpkin and Dess, 2001). We draw on the results of these studies in our conceptualization and hypothesis development in the next section (2.2).

Finally, somewhat surprisingly, there is scarce evidence in the existing literature on the interactions between the dimensions of EO. Exceptions include Tang et al. (2009), Lomberg et al. (2017), Linton and Kask (2017), and Rigtering et al. (2017). We relate our findings to these papers in Section 5 .

\subsection{A new conceptualization of interrelations between the dimensions of EO}

We propose a new conceptualization of how the dimensions of EO come together in driving performance. Figure 1 provides a schematic illustration of the conceptual framework and the hypotheses. We propose that risk taking has a direct, positive effect on performance. Innovativeness moderates (strengthens) the effect of risk taking on performance by affecting the type of risk taking. And, proactiveness has a positive effect on performance through its effect on the level of risk taking.

\section{$<$ Figure $1>$}

In the remainder of this section, we elaborate on the reasoning that underpins this conceptual model of the interrelations between the dimensions of EO and we develop hypotheses. We start by considering which dimensions of EO have a direct relationship with performance. We then consider which dimensions have indirect relationships with performance through mediation and moderation. 


\subsubsection{Direct effects of innovativeness, proactiveness, and risk taking on performance}

Several studies argue that EO is an innovation-based construct and that innovation has a direct and positive effect on the performance of firms (e.g., Baker and Sinkula, 2009; Wheelwright and Clark, 1992; Deschryvere, 2014; Grifith et al., 2006; Yasuda, 2005). The focus on innovation is partly attributable to the fact that EO has often been evaluated in manufacturing settings where innovation in products or processes is rather tangible (Pearce et al., 2010; Covin and Slevin, 1989; Wiklund, 1999; Wiklund and Shepherd, 2003, 2005). Innovativeness also forms an important part of the classical conceptualizations of entrepreneurship (e.g., Drucker, 1985; Schumpeter, 1934).

Risk taking is also highlighted in the entrepreneurship literature as a central feature of entrepreneurship and a contributor to performance. The recognition of risk taking as a fundamental part of entrepreneurship has a long history. For example, in 1755, Richard Cantillon, who is credited with introducing the term "entrepreneur", noted the role of uncertainty in entrepreneurship (Hebert and Link, 1988). More recently, Linton and Kask (2017, p. 169) describe risk taking as a key factor in the origins of EO: "the roots of entrepreneurial orientation are related to the fact that entrepreneurial firms are more inclined to take risks than other types of firms." Thus both risk taking and innovativeness have long been seen as elements that drive the entrepreneurial process and performance.

Risk takes many forms. An important distinction dating back to Knight (1921) and Keynes (1921) is between "risk" and "uncertainty" / "ambiguity". "Risk" refers to a situation where probabilities of outcomes are known or can be estimated from past data, whereas "uncertainty" or "ambiguity" is a situation where probabilities of outcomes are themselves uncertain or unknown, such as when embarking on unprecedented endeavors. ${ }^{6}$ Even though much of the entrepreneurship literature, including Miller (1983), Covin and Slevin (1989), and Lumpkin and Dess (1996), does not

\footnotetext{
${ }^{6}$ For more detailed discussion of risk and uncertainty, see Gilboa et al. (2008), Gilboa (2009), and Wakker (2010).
} 
explicitly discuss the distinction between risk and uncertainty, it is clear they consider "risk taking" in entrepreneurship as involving both "risk" and "uncertainty". 7

Risk and uncertainty have been extensively studied outside of the entrepreneurship and management literature. For example, financial economics theory is largely about behavior under risk and uncertainty and the resulting outcomes. The positive relationship between risk and return is the cornerstone of financial economics (Soininen et al., 2012). Harry Markowitz, pioneer of Modern Portfolio Theory, built his theory of investment around the notion of risk aversion. He recognized that for a given level of return, investors generally prefer investments with lower risk and for a given level of risk, investors prefer higher returns (Markowitz, 1952). Consequently, investors typically only take on higher risk if it carries a higher expected return, driving a positive relationship between risk and return.

People also have an inherent aversion to uncertainty/ambiguity, which drives a positive relationship between uncertainty and returns. ${ }^{8}$ For example, the classic experiment by Ellsberg (1961) illustrates that people prefer bets with known probabilities compared to bets with unknown probabilities (ambiguity aversion), resulting in higher returns for gambles that involve uncertainty in addition to risk. Entrepreneurs also display risk and ambiguity aversion, although they may have a higher propensity for risk-taking and a greater tolerance for ambiguity (e.g., Schere, 1982; Begley and Boyd, 1987). Therefore, the positive relationship between risk/uncertainty and return/reward that is found in a large number of decision-making contexts is also likely to hold in entrepreneurship.

To better understand how risk taking is related to performance in entrepreneurship, we draw on financial economics theories that show how the relationship between risk and return arises in investment contexts. One of the most fundamental asset pricing theories in financial economics, the Capital Asset Pricing Model (the "CAPM"; Sharpe, 1964; Lintner, 1965), builds on Markowitz's

\footnotetext{
${ }^{7}$ See McMullen and Shepherd (2006) for further discussion on uncertainty in entrepreneurship contexts.

${ }^{8}$ For reviews of some of the evidence, see Weber and Camerer (1987) and Camerer and Weber (1992).
} 
portfolio theory and postulates that the expected return of an investment (e.g., shares in a company) will be positively related to the riskiness of the investment. Subsequent asset pricing theories account for both risk and uncertainty/ambiguity. For example, Epstein and Wang (1994) and Chen and Epstein (2002) develop the theory of Intertemporal Asset Pricing under Ambiguity in which investors make investment decisions without full knowledge of the probabilities of outcomes, similar to the nature of risk taking in entrepreneurship. ${ }^{9}$ This theory also shows that a positive relationship arises between uncertainty and the return of an investment due to an "ambiguity premium" (Epstein and Schneider, 2010). While the ambiguity premium is distinct from the risk premium, the intuition for both is similar - because investors dislike uncertainty, they only invest in more uncertain prospects if they carry the expectation of higher returns.

Risk/uncertainty aversion is likely to drive a positive relation between venture-level risk taking and performance, through (i) decisions within firms about which strategies or projects to pursue and (ii) decisions about which ventures to undertake in the first place. Starting with the first of these, major decisions within firms often involve explicitly or implicitly applying the principle that higher risk projects require higher expected returns. For example, Graham and Harvey (2001) survey chief financial officers (CFOs) of US firms and find that the CAPM is the most widely used method for obtaining a required return when making corporate investment decisions. This practice leads firms to undertake riskier or more uncertain projects only when those projects have higher expected returns. A similar result is likely to emerge in firms that do not formally apply the financial economics models. It is sufficient that in making investment decisions, due to risk/uncertainty aversion, managers select projects with high risk or uncertainty only if they have high expected payoffs.

Risk/uncertainty aversion in making decisions about which ventures to purse also drives a positive relationship between risk taking and performance. For example, consider an entrepreneur that

\footnotetext{
${ }^{9}$ A large number of other papers contributed to developing the theory; for reviews of this literature, see Epstein and Schneider (2010) and Guidolin and Rinaldi (2013).
} 
faces the choice of launching a venture in a fast-moving, high risk, high uncertainty technology sector or a lower risk, less uncertain, more established traditional sector. If the expected performance is the same in both sectors, an entrepreneur with typical preferences (risk and uncertainty aversion) would choose the lower risk/uncertainty sector. This choice increases competition in the lower risk/uncertainty sector, decreasing growth and profit opportunities in that sector compared to the other sector. This process of adjustment would continue until the expected performance in the high risk/uncertainty sector is sufficiently high compared to the low risk/uncertainty sector such that entrepreneurs are indifferent between competing in either sector. The result is a positive relationship between venture-level performance and venture-level risk taking. We therefore hypothesize:

Hla: Risk taking has a direct positive relationship with performance.

Our hypothesis is consistent with Knight's (1921) view of entrepreneurship, in which the entrepreneurial rents (or performance) are the returns to the entrepreneur from bearing uncertainty/ambiguity. It is also consistent with more recent characterizations of entrepreneurship (such as Shane and Venkataraman, 2000, and Shane, 2003) in which entrepreneurs exploit opportunities when they believe that the expected value of the entrepreneurial profit will be large enough to compensate for the opportunity cost of other alternatives, the lack of liquidity of the investment, and importantly, a premium for bearing risk and uncertainty. Finally, it is also consistent with the implications of equilibrium models of entrepreneurship decisions such as Khilstrom and Laffont (1979) and Bewley (2001).

Should the relationship between risk taking and performance be linear or nonlinear? It is likely that beyond a certain point, additional risk taking becomes reckless and can harm performance. Therefore, in theory, if one could exogenously vary risk taking from very low to very high levels, one 
could observe a point at which the relationship between risk taking and performance becomes negative (an inverse $\mathrm{U}$ shaped relationship). However, in practice, we only observe the levels of risk taking chosen by entrepreneurs that try to maximize performance. If entrepreneurs recognize that excessive risk taking is harmful, then empirically, one might not observe the downward sloping segment of the inverse $U$ curve and the empirically observed relationship may simply be positive. Furthermore, the shape of the relationship between risk taking and performance depends on the measures of risk and performance. For example, if there is a linear relationship between performance and risk measured by standard deviation of outcomes, then there is a nonlinear, concave (square root) relationship between performance and risk measured by variance.

A further implication of financial economics theory is that not much other than the degree of risk and uncertainty should determine expected returns. The intuition is that if some factor was able to predict future returns (other than through its relationship with risk), profit-seeking investors would exploit that information and compete to invest in financial assets with high expected risk-adjusted returns. In doing so, they bid up the prices of those assets, thereby reducing the expected returns until they are proportional to the level of risk/uncertainty. With competition among investors, the adjustment should be rapid and therefore factors other than risk/uncertainty are unlikely to determine expected or average returns.

An analogous mechanism is likely to determine the relationship between venture-level strategy and performance. For example, consider an entrepreneur that faces the choice of two equally risky/uncertain strategies: produce a product for the low-quality low-cost segment of the market, or alternatively produce for the high-quality high-cost segment. If one of the strategies has better expected performance, say the high-quality strategy, then entrepreneurs will be inclined to follow that strategy. This choice increases competition in the high-quality segment, thereby decreasing growth and profit opportunities in that segment compared to the other segment. This process of adjustment 
will continue until the expected performance of each strategy is equal (given that the strategies in this example were assumed to have equal risk and uncertainty). If the strategies involve different levels of risk or uncertainty, the adjustment would continue until the expected performance of each strategy is proportional to its risk/uncertainty. Thus, venture-level strategy should not be related to performance, except through its association with risk/uncertainty.

The reasoning above implies that while risk taking is likely to be directly, positively related to firm performance, other aspects of strategy or entrepreneurial orientation (e.g., innovativeness and proactiveness) are unlikely to be direct drivers of performance. Rather, the other aspects of strategy or entrepreneurial orientation are likely to impact performance through their association with risk taking, i.e., indirectly. If there was a direct relationship between innovativeness or proactiveness and performance that was independent of risk taking, say if innovation offered high performance holding risk constant, opportunistic entrepreneurs would exploit the opportunity by increasing innovativeness within ventures or undertaking new, highly innovative ventures, thereby competing away the rewards to innovation. We therefore extend our first hypothesis with a second part:

H1b: Elements of venture-level strategy/orientation (such as proactiveness and innovativeness) that have a relationship with performance obtain this relationship through their association with risk taking.

Hypothesis $H I b$ is contingent on a few things. First, the hypothesis requires that firms can choose their entrepreneurial orientation, e.g., increase or decrease innovativeness and proactiveness to optimize performance. If, instead, some elements of entrepreneurial orientation such as innovativeness cannot be chosen and are skills that entrepreneurs either possess or do not possess 
then inability for entrepreneurs to compete with respect to such characteristics may allow some characteristics to also have a direct association with performance.

Second, hypothesis $H 1 b$ relies on competition among entrepreneurs. This means that entrepreneurs are informed of profit opportunities, they actively seek to maximize performance to avoid being driven out of business by more competitive ventures, and the cost of altering venturelevel strategy to exploit profitable opportunities is relatively low.

\subsubsection{Indirect effects of proactiveness and innovativeness on firm performance}

While it is possible for innovativeness and proactiveness to affect performance through mediating or moderating relationships, for reasons that we will explain, it is more likely that proactiveness affects the level of risk taking and innovativeness affects the nature or type of risk taking. We consider the role of proactiveness first, followed by innovativeness.

A number of studies highlight that proactive behaviors involve risk taking — being the first to exploit opportunities and acting as a market leader in anticipating future demand is inherently risky (Lumpkin and Dess, 2001; Smith and Cao, 2007; Hughes and Morgan, 2007). Proactive enterprises gain a competitive advantage in the marketplace through their anticipation of future market conditions and leadership in discovering and exploiting opportunities (Venkataraman, 1989; Covin et al., 2000; Lumpkin and Dess, 2001). Such leadership often involves acting on less complete or precise information than a less proactive strategy, suggesting proactiveness requires taking calculated risks. Similarly, Hughes and Morgan (2007, p.653) argue that "risk aversion renders firms passive to developing new market opportunities, which is likely to deteriorate performance in an age of rapid change." In other words, proactively developing new market opportunities requires the firm be willing to take risks, and the effect of such proactiveness (via risk taking) is increased performance, in particular in dynamic environments involving rapid change. 
In a similar vein, Tang et al. (2009, p.196) specifically highlight the important role played by proactiveness as a driver of risk taking: "entrepreneurial firms first display proactive behaviors which results in increased perceptions of environmental opportunities. Then, the firms utilize innovative and risk-taking behaviors to capitalize on these opportunities. Thus, proactiveness appears to represent the first link in the hierarchical relationship between the dimensions of entrepreneurial orientation."

Kreiser et al. (2013) argue that superior performance among small and medium enterprises (SMEs) can be attributed to risky activities that are deliberately undertaken to capitalize on emerging market opportunities. The essence of their argument is that because the future is uncertain, proactiveness is likely to involve greater risk than acting in response to the actions of other firms and changes in demand. These arguments again imply that proactiveness is positively related to performance via its positive effect on the level of risk taking.

Another way that proactiveness is likely to affect performance via risk taking is when firms engage in strategic learning via exploratory action. Strategic knowledge, which is an important driver of firm competitiveness, is generated through experimental and exploratory actions (Anderson et al., 2009). Exploratory action is implicit to the proactiveness dimension of EO (Covin and Slevin, 1991) and involves risk taking. Therefore, proactiveness in the form of exploratory action increases risk taking and, in turn, is likely to result in better performance.

The reasoning above leads to the following hypothesis:

H2: Proactiveness has an indirect, positive relationship with performance via risk taking as a mediator.

To the extent that innovative strategies also involve risk taking, innovativeness could also affect performance through risk taking as a mediator. There is, however, greater scope to take actions 
that reduce the risk associated with innovation. For example, a firm that decides to pursue an innovative approach and is conscious of the inherent risks could hold a larger cash balance (use less leverage) to reduce the risk of not being able to meet short term financial obligations. Additionally, an innovative firm might conduct more extensive market research on product viability to reduce the risk of investing in developing a product doomed to fail. Such actions could offset the risks typically accompanied by innovative behavior and thus change the composition or types of risk that the venture is exposed to without necessarily changing the overall level of risk.

Not all types of risk taking are expected to increase performance. This is the case in financial economics theories such as the CAPM (Sharpe, 1964; Lintner, 1965) and it is also likely to be the case in corporate decision making and entrepreneurship. There are many risks that will not necessarily increase expected performance; for example, not hedging interest rate risk on exports or imports, taking on excessive levels of leverage, or not undertaking market research before launching a new product. Such risks increase the variability of performance but do not necessarily lead to better expected performance. Other risks, however, are likely to be associated with higher expected performance; for example launching new products and entering new markets. We refer to the two types of risks as non-constructive and constructive risks, respectively. The defining feature of constructive risks is that they are expected to increase performance.

The risks associated with innovative strategies are likely to be constructive. Innovativeness involves creating new products and/or technological leadership (Covin and Slevin, 1991), which requires large upfront expenditure on R\&D (Hornsby et al., 2009; Rosenbusch et al., 2011) and uncertain payoffs. Innovation is considered by many entrepreneurship scholars as an important driver of growth and creation of products or services with high profit potential (Cho and Pucik, 2005; Wiklund et al., 2009). Thus, it is not surprising that several studies find a positive link between innovativeness and performance (Terziovski, 2010; Rosenbusch et al., 2011). Miller (1983, p.780) 
also suggests that risk taking is "entrepreneurial" when it is associated with innovation: "by the same token, risk-taking firms that are highly levered financially are not necessarily considered entrepreneurial. They must also engage in product-market or technological innovation."

The resource-based view of the firm provides further reasons why innovativeness might be a moderator of the relationship between risk taking and performance (e.g., Kolmann and Stöckmann, 2012). Under a resource-based view, risk taking is a highly resource-absorbing orientation because it involves committing large volumes of resources to endeavors with uncertain outcomes (Miller and Friesen, 1978; Lumpkin and Dess, 1996; Wiklund and Shepherd, 2003; Rauch et al., 2009). Firms are likely to have an implicit "risk budget", i.e., a constraint on the resources that can be allocated to risky endeavors. At the same time, innovativeness also requires substantial resources and might compete with other strategies for a share of the firm's resources (Raisch and Birkinshaw, 2008). When resources are constrained, firms might be forced to combine the competing demands and, for example, engage in innovative risk taking. As a consequence, innovativeness is likely to affect the type of risk taking within the firm, orientating it towards innovative activities.

We therefore hypothesize that innovativeness has a moderating effect on the risk-performance relationship by affecting the extent to which risks taken by the firm are constructive:

\section{H3: The positive relationship between risk taking and performance is strengthened by} innovativeness.

While we have identified reasons why it is likely that innovativeness affects performance through a moderating relationship and proactiveness through a mediating relationship with risk taking, it is possible that proactiveness also moderates the effect of risk taking and innovativeness 
increases the amount of risk taking. These alternatives are not mutually exclusive and therefore our empirical analysis will explore these alternative hypotheses.

\section{Data and descriptive statistics}

\subsection{Sample, variables, and measures}

We construct a stratified random sample of companies from three European Union member states - Estonia, Latvia and Lithuania — by taking equal sized random samples within each size decile within each country. We obtain the lists of all companies in each of the countries from the Orbis database maintained by Bureau Van Dijk.

We administer a questionnaire via telephone interviews and collect 1,020 responses with complete information on the items required to compute entrepreneurial orientation. The telephone interviews are conducted with company owner/managers during March and April, 2011. The original survey was written in English language. It was translated to Estonian, Latvian, Lithuanian, and Russian languages by a professional translator in each of the countries. The translated surveys were then provided to another, independent, translator in each country to translate back into English language. We reviewed the reverse-translated surveys (the surveys that had been translated back into English language) and compared them to the original English language survey to identify any ambiguities or instances of altered meaning, which was subsequently corrected by a professional translator.

The overall response rate across all three countries is $37.4 \% .^{10}$ The response rate varies across countries, with a rate of $31.7 \%$ in Lithuania, $32.0 \%$ in Latvia, and $57.6 \%$ in Estonia. Results from a probit model explaining the response rates indicates that the higher response rate in Estonia is partly due to the fact that firms in Estonia tend to be smaller and smaller firms tend to have higher response

\footnotetext{
${ }^{10}$ See the Online Appendix for a discussion of typical response rates.
} 
rates, although other country-specific factors unrelated to firm size also affect the response rate. There is less variation in the response rate across industries, with the lowest rates being $32.9 \%$ in Wholesale Trade and 33.3\% in Transport and Utilities, and the highest rate being $46.1 \%$ in Services. We conduct tests of how the non-response affects our results (we apply Heckman selection bias corrections to our models; see Section 4 of the Online Appendix) and find that our results are not strongly influenced by non-response bias, consistent with Wiklund and Shepherd (2011). If anything, the results are stronger in the selection-corrected models.

Runyan et al. (2012) examine the cross-cultural invariance of the EO construct and conclude that it is generally valid cross-culturally and scholars should feel confident using the EO scale in Western and non-Western cultures when at least configural and metric invariance is needed. Furthermore, the EO-performance relationship has been studied in a wide range of countries including the US, UK, Australia, China, Sweden, Germany, Vietnam, Taiwan, Korea, Malaysia, and Fiji, and the overwhelming evidence suggests that the effects are relatively homogenous across these very different settings, including different types of economies (see Rauch et al. (2009) for a review). Finally, Rieger et al. (2015) conduct a large-scale international survey across 53 countries and find that respondents in all countries exhibit risk aversion in gains, which is an important component of our hypotheses about risk taking and performance. For these reasons, we believe our results generalize beyond the three countries contained in our sample.

\section{$<$ Table $1>$}

Table 1 reports the composition of the sample by sector and by country. Latvian and Estonian firms are slightly overrepresented relative to Lithuanian firms. Approximately one third of the firms 
in the sample operate in the services sector and the remaining two thirds are fairly equally divided between manufacturing, wholesale, retail, and construction.

We measure entrepreneurial orientation (EO) from responses to ten pairs of opposite statements that describe various aspects of EO. The full list of questions is available in the Online Appendix. The questions are arranged so that the entrepreneurial and non-entrepreneurial statements appear at both the right- and left-hand sides of the seven-point scale. Eight of the ten items are from Covin and Slevin (1989). We supplement these with one further item measuring innovation from Lumpkin (1998) and Lumpkin et al. (2009) and one further item measuring proactivity from Lumpkin and Dess (2001). We construct innovativeness, risk taking, and proactiveness factors by taking the first principal component of responses to the questions relating to the particular EO dimension. The EO factor is constructed by taking the first principal component of the innovativeness, risk taking, and proactiveness factors. Cronbach's alpha for EO is 0.63 , which is similar to the value obtained in previous studies.

Performance is a multidimensional concept and previous studies have used different measures of performance as well as combined measures. We follow a similar approach to Wiklund and Shepherd (2005) and combine measures of financial performance and growth. Specifically, we record firms' self-reported year-on-year percentage change in profits, percentage change in sales revenue, and percentage change in number of employees and calculate performance as the first principal component of the three variables. Cronbach's alpha for this construct is 0.71 , which is similar to previous studies. In robustness tests we find that our main results also hold for each individual component of performance in place of the combined performance measure.

The size, age, and sector of a firm may influence its strategy, EO, and performance. Therefore in our multivariate analysis we control for firm size (natural logarithm of the number of employees), firm age (number of years since the company was registered), and sector (manufacturing, wholesale, 
retail, services, construction, and other). Because our sample spans three countries we also control for the country in which the firm operates. Our results are robust to adding additional control variables including sales revenue, average wage, and management experience.

\subsection{Descriptive statistics and correlations}

Table 2 reports the means, standard deviations, and correlations between the variables of interest. The average firm in our sample is around 12 years old, has approximately 48 employees, and annual revenue of EUR 4 million. The average size of the firms varies across the countries, with the largest being in Lithuania (average of 87 employees and EUR 6 million revenue), followed by Latvia (47 employees and EUR 5 million revenue), and then Estonia (13 employees and EUR 2 million revenue). Profits and revenue tend to increase year-on-year among the firms in our sample (by approximately $19 \%$ and $9 \%$, respectively), but the number of employees decreases slightly (3\% on average).

$<$ Table $2>$

The correlation between EO and performance is 0.18. Although there is quite a degree of variation in the reported strength of the EO-performance relationship across previous studies, a recent meta-analysis using 53 samples from 51 studies estimates the overall correlation to be 0.24 (Rauch et al., 2009). Therefore, the strength of the EO-performance relationship in our sample is of a similar magnitude to the average strength across a large number of previous studies. Each of the dimensions of EO also has a positive correlation with performance, between 0.12 and 0.16 .

The components of EO (innovativeness, risk taking, and proactiveness) are positively correlated with one another. Their correlations range from 0.21 to 0.44 . The dimensions of EO have correlations with EO between 0.70 and 0.84. Similarly, the correlations between the components of 
performance (changes in profits, changes in revenue, and changes in employees) are between 0.28 and 0.58 , indicating consistency among the components.

\section{Empirical analysis}

\subsection{Direct effects of innovativeness, proactiveness, and risk taking on firm performance}

Our approach to analyzing the interrelations between the dimensions of EO and identifying the direct and indirect drivers of performance involves estimating a sequence of regressions that iteratively arrive at the model that best fits the data. We begin by establishing that a statistically significant and economically meaningful relationship exists between EO and performance. We then separate the three key dimensions of EO and test the individual effects of innovativeness, risk taking, and proactiveness on performance, controlling for the other dimensions of EO.

Table 3 reports the coefficients and fit statistics of a series of regressions testing the EOperformance relationship as well as mediating and moderating relations, which we describe in the next section. Model 1 regresses performance on EO and control variables. The model confirms that EO is significantly positively related to performance as documented in many previous studies. Because EO and performance are standardized to have zero mean and unit standard deviation, the results indicate that a one standard deviation increase in EO is associated with an increase in performance of approximately 0.13 standard deviations.

\section{$<$ Table $3>$}

Model 2 separates the three dimensions of EO. The results indicate that of the three dimensions, only risk taking has a significant relationship with performance controlling for the other dimensions of EO. The relationship between risk taking and performance is of similar magnitude to 
that of EO and performance, whereas the coefficients of innovativeness and proactiveness are close to zero. This suggests that only risk taking has a direct effect on performance, consistent with hypothesis H1. Further evidence that innovativeness and proactiveness do not have a direct association with performance comes from comparing regression Models 1 and 6. Replacing EO as the independent variable that explains performance with risk taking as the independent variable (moving from Model 1 to 6), which is equivalent to dropping innovativeness and proactiveness from the EO construct, improves the model fit (R-squared) and increases the strength of the relationship with performance. Therefore, the empirical results support hypothesis $H 1$.

When we do not control for risk taking as an independent variable, innovativeness and proactiveness have a positive and statistically significant unconditional relationship with performance (Models 5 and 7). Since these relationships become insignificant when controlling for risk (the conditional relations in Model 2), innovativeness and proactiveness are associated with performance indirectly, that is, through their relationship with risk taking. There are at least two indirect ways that innovativeness and proactiveness can affect performance through their relationship with risk taking: (i) by influencing the level of risk taking and (ii) by influencing the type of risk taking. The former implies a mediating relationship whereby a higher level of innovativeness or proactiveness leads to a higher level of risk taking (the mediator), which in turn leads to higher performance (a chain of effects). ${ }^{11}$ The latter implies a moderating relationship, whereby the type of risk taking that occurs in highly innovative/proactive firms has a stronger effect on performance than does risk taking in less innovative/proactive firms. We test for both mediating and moderating effects in the next subsection. $^{12}$

\footnotetext{
${ }^{11}$ See Preacher and Hayes (2004) for a discussion of how a chain of effects implies a mediated relationship.

12 See Arnold (1982) for a discussion of how a moderated relationship arises when one variable affects the strength of the relationship between two other variables.
} 


\subsection{Indirect effects of innovativeness and proactiveness on firm performance}

\subsubsection{Tests of moderating relations}

We test for moderating relations between the dimensions of EO using an approach similar to the hierarchical linear regression analysis in Wiklund and Shepherd (2005). Models 3 and 4 (in Table 3) iteratively build on the regression of performance on the three EO dimensions (Model 2) by adding two- and three-way interactions of innovativeness and proactiveness with risk taking. The interaction terms test whether innovativeness and proactiveness individually or jointly strengthen or weaken the relationship between risk taking and performance. In Model 4, the coefficient of the interaction term between risk taking and innovativeness is positive and statistically significant at the $90 \%$ confidence level (p-value $<0.10$ ). The result suggests that risk taking that is associated with a high level of innovativeness is related to better performance than risk taking that is associated with a low level of innovativeness. Given that the subsequent analysis suggests the effect is of a meaningful magnitude, the absence of a higher degree of statistical significance is likely due to moderate or low statistical power of the tests from factors such as noise in the variables. ${ }^{13}$

There is no evidence of a moderating relationship for proactiveness, nor is the joint effect of innovativeness and proactiveness on the relationship between risk taking and performance significant. Therefore, the empirical results support the hypothesis $H 3$, i.e., that innovativeness positively moderates the relationship between risk taking and performance. We do not find support for proactiveness as a moderator.

$<$ Figure $2>$

\footnotetext{
${ }^{13}$ The results are very similar when we include the third two-way interaction term, Innovativeness $*$ Proactiveness, in Models 3 and 4 (the coefficient on the term Innovativeness*Proactiveness is not statistically distinguishable from zero). We treat this as a robustness test because unlike the other interaction terms our hypotheses do not predict a role for Innovativeness*Proactiveness (and the insignificant coefficient supports this view).
} 
To explore the magnitude of the moderating influence of innovativeness, Figure 2 plots the relationship between risk taking and performance for three levels of innovativeness (high, average, and low) holding other variables fixed at their means. High, average, and low innovativeness refers to one standard deviation above the mean, the mean, and one standard deviation below the mean level of innovativeness. The slopes in Figure 2 indicate that innovativeness has an economically meaningful influence on the extent to which risk taking is rewarded with higher performance.

\subsubsection{Tests of mediating relations}

To test for mediated relationships between the dimensions of EO and performance we follow the approach advocated by Preacher and Hayes (2004). This approach can be applied by estimating a series of regression models: (i) regression of the mediator $(\mathrm{M})$ on the independent variable $(\mathrm{X})$ with the coefficient denoted $a$; (ii) regression of the dependent variable $(\mathrm{Y})$ on the independent variable (X) with the coefficient denoted $c$; and (iii) regression of the dependent variable (Y) on both the independent $(\mathrm{X})$ and mediator $(\mathrm{M})$ variables with the coefficient on the mediator variable denoted $b$. A mediated relationship exists if the relationship between the dependent and independent variables via the mediating variable (i.e., the product of coefficients $a \times b$ ) is statistically significant. Preacher and Hayes provide the test statistic for evaluating the significance of the mediation effect. This approach allows the strength of the indirect (mediation) channel $(a \times b)$ to be expressed as a proportion of the total effect $(c)$.

Table 3 provides the estimates from the regressions described above. The results indicate that there is a statistically and economically significant mediated relationship between proactiveness and performance through risk taking as the mediating variable. The mediation channel is statistically significant with a p-value less than 0.01 and accounts for $53 \%$ of the total effect of proactiveness on 
performance. $^{14}$ In contrast, the direct effect of proactiveness on performance is not statistically distinguishable from zero (Model 2 in Table 3). Therefore, the empirical results provide strong support for hypothesis $H 2$ that proactiveness drives performance by increasing risk taking.

The results also indicate that innovativeness does not have a significant mediated effect on performance and therefore differs from proactiveness in how it relates to performance. ${ }^{15}$ Consistent with proactiveness (but not innovativeness) having a mediated relationship with performance through risk taking, Model 10 in Table 3 shows that only proactiveness remains statistically significant when both proactiveness and innovativeness are included as determinants of risk taking.

\subsubsection{Robustness tests}

As a robustness test, we include additional control variables including sales revenue, average wage, and management experience and find that our results continue to hold and in most cases become even stronger.

We also test for nonlinearities by including quadratic forms of the key independent variables. Generally the coefficients of the quadratic terms are not statistically distinguishable from zero and the previous results continue to hold suggesting nonlinearities do not play a significant role. There are two points to note about this result. First, as described in the theoretical framework, a linear positive empirical relationship between risk taking and performance can emerge even if the theoretical relationship between risk taking and performance takes an inverse $\mathrm{U}$ shape. For example, if the actual relationship is inverse $\mathrm{U}$ shaped, but entrepreneurs rarely engage in excessive or reckless risk taking that harms performance, then only the positive section of the relationship will be observed in the data. Second, the relationship between any of the dimensions of EO and performance is dependent on how

\footnotetext{
${ }^{14}$ The mediation channel strength is $a \times b=0.051$ (obtained from Models 2 and 9 in Table 3 ) and the total effect is $c=0.098$, making the mediation channel $(a \times b) / c=53 \%$ of the total effect.

${ }^{15}$ Constructing the test statistic using Models 2 and 8 in Table 3 gives a p-value of 0.39 for the mediation effect.
} 
the measures are defined. It is therefore possible that other measures of performance, risk taking, innovativeness, or proactiveness will have non-linear relationships.

We examine potential non-response bias and find that our results are robust to this potential bias (see Section 4 of the Online Appendix). Finally, we also examine alternative forms of the performance variable, for example, by constructing a performance factor from only two of the three variables used in the main specification or using each of the components of performance separately. We find that the main results continue to hold.

\section{Discussion and implications}

The data support our reconceptualization of how the components of EO combine and interact in driving performance. The key elements are that risk taking has a direct, positive effect on performance, which depends on the level of innovativeness, and proactiveness has an indirect positive effect on performance through risk taking. Therefore, each dimension of EO has a positive effect on performance but for different reasons. These interactions between the dimensions of EO and their link to performance are summarized in Figure 1.

Our finding that neither innovativeness nor proactiveness has a direct, independent effect on performance does not invalidate EO as a construct. We show that innovativeness and proactiveness are associated with positive performance, but that this association is through their effects on, or interaction with, risk taking. Thus, the reason why each of the three dimensions is positively related to performance is different in each case: (i) risk taking is rewarded because, all else equal, risk is undesirable; (ii) proactiveness tends to increase risk taking; and (iii) risk taking that is associated with a high level of innovativeness tends to give better payoffs than risk taking that is associated with low or average innovativeness. This distinction between the different ways in which each of the 
dimensions contributes to performance is subtle, but is important in understanding the mechanisms that underpin the EO-performance relationship.

Our conceptual model and empirical results have a number of implications and suggest directions for future research. First, we have shown that, consistent with theory, risk-taking is a direct determinant of performance. Our conceptual model proposes that other elements of venture-level strategy, orientation, and firm characteristics that relate to performance obtain this relation through their association with risk-taking; either by affecting the amount or type of risk taking. While our empirical analysis supports the notion that innovativeness and proactiveness are related to performance through their association with risk taking, we conjecture that the same is true of other elements of strategy/orientation. It would be useful to explore this conjecture in future work in either of two ways: (i) for elements of strategy or orientation that are associated with performance, examine how they relate to risk taking and whether their relationship with performance occurs via, or in association with, risk taking; and (ii) for elements of strategy or orientation that are related to risk taking, examine how their relationship with risk taking gives them an indirect relationship with performance.

Second, the hypothesis that risk taking has a direct, positive relationship with performance, while other elements of strategy/orientation obtain their relation with performance through their association with risk taking was built on the premise that: (i) firms can choose their entrepreneurial orientation (e.g., increase or decrease innovativeness and proactiveness to optimize performance); and (ii) there is competition among entrepreneurs. Thus, the empirical support for this hypothesis is consistent with innovativeness and proactiveness at the firm level being deliberate strategies as opposed to traits that a firm either has or does not have. The evidence also suggests entrepreneurs are informed of profit opportunities and actively seek to exploit profitable opportunities. This suggests a relatively "efficient" entrepreneurship market analogous to the Efficient Markets Hypothesis (Fama, 
1965). High efficiency occurs when a large number of competing and well-informed investors or entrepreneurs seek out and exploit attractive opportunities, information about such opportunities is relatively easy to obtain, and there are few frictions that impede profit seeking activities. Future research might investigate the contextual dependence of this hypothesis, for example, whether it continues to hold in environments characterized by a low degree of competition or lack of information about opportunities. Future research might also investigate whether there are elements of orientation/strategy that cannot be freely chosen and thus might not be subject to the same competitive forces. For example, perhaps personality traits or conditions that cannot be learned or adopted.

Third, our results suggest that innovativeness affects the types of risk that a venture is exposed to in a beneficial way, but not necessarily the total level of risk. In contrast, proactiveness is associated with an increased level of risk taking, but does not necessarily increase performance per unit of risk. Future research might further investigate this distinction between types and levels of risk and whether our results reflect a tendency for innovative firms to take actions to reduce the additional risk that is inherent in an innovative strategy. For example, do innovative firms maintain higher cash balances or levels of leverage to reduce the risk of not being able to meet short term financial liabilities, or do they engage in more market research to reduce the chance of product failure?

Fourth, our results should not be interpreted as suggesting that a firm can increase its performance simply by taking on any risks. In theorizing about how the dimensions of EO affect performance we made the distinction between constructive risks - those that increase expected performance - and non-constructive risks. Unhedged exposure to commodity prices or exchange rates, excessive leverage, as well as recklessness are examples of non-constructive risks: they increase the variability of performance, increasing the likelihood of financial distress and bankruptcy, but are unlikely to increase performance. Interestingly, Walls and Dyer (1996) also distinguish 
between risk that improves venture-level performance and risk that is detrimental, calling the latter "hazardous" risk to indicate it threatens the financial stability of the venture without contributing to performance.

There is relatively little guidance in the entrepreneurship literature about what constitutes a constructive and a non-constructive risk. We see this as another promising area for future research. Our empirical results provide some guidance by indicating that risk taking by firms that have a high level of innovativeness tends to be related to higher performance than risk taking by firms with lower levels of innovativeness. Thus innovativeness is one of the determinants of the constructiveness of risk taking. There is, however, scope for much more research in delineating constructive and a nonconstructive risk taking in an entrepreneurship context. One approach is to consider other factors that moderate the effect of risk taking on performance, thereby shedding light on what makes risks more "constructive".

Fifth, there is some (although mixed) evidence in the existing literature that the EOperformance relationship might be nonlinear. A potential explanation consistent with our results is that a simple linear model between EO and performance (implying that each of the dimensions of EO has a direct and positive relationship with performance) is mis-specified because it does not account for interactions between the dimensions of EO. Because innovativeness has a moderating effect and proactiveness has a mediated relationship with performance via risk taking, the relationship between EO and performance need not be linear. For example, if all three dimensions of EO double in value, leading to a doubling of $\mathrm{EO}$, the effect of $\mathrm{EO}$ on performance could be more than double because, among other reasons, the interaction between innovativeness and proactiveness provides an additional increase in performance. While our findings provide a potential explanation for non-linearity in the EO-performance relationship, this is a complex issue that would benefit from more detailed examination in future research. 
Our conceptualization and empirical findings complement and extend existing studies that disaggregate the dimensions of EO. For example, Lomberg et al. (2017) use commonality analysis to decompose the variance in performance that is associated with innovativeness, proactiveness, and risk taking into parts that are associated with the covariation in these components ("shared effects") and parts that are due to unique variation in the components ("unique effects"). They find that about onethird of EO's total effect is explained by shared effects (bilaterally shared effects between pairs of dimensions and common shared effects that involve all three dimensions). This is an important finding because it indicates that the mechanisms underpinning how the components of EO affect performance are complex and involve both unique roles and interactions.

The commonality analysis employed by Lomberg et al. (2017), however, does not identify the specific configuration of the EO dimensions that gives rise to the unique and shared effects. Nor does it identify the specific interrelations between the EO dimensions. A number of different configurations could produce the shared/unique effects that they find. In fact, Lomberg et al. (2017) suggest expanding the existing conceptualizations of EO in a way that accounts for both unique and shared effects. This is precisely the step that our paper takes. Thus, our paper builds on the finding of Lomberg et al. (2017) that both shared and unique effects are important, and provides a model of how the dimensions EO are configured in driving performance. We shed light on mechanisms that result in the variance characteristics documented by Lomberg et al. (2017).

Somewhat surprisingly, very few studies have formally examined interrelations between the dimensions of EO. A noteworthy exception is Tang et al. (2009) who analyze the interrelations between the components of EO and opportunity perceptions, using a hierarchical model. Tang et al. (2009, p.196) highlight an important role for proactiveness: "entrepreneurial firms first display proactive behaviors which results in increased perceptions of environmental opportunities. Then, the firms utilize innovative and risk-taking behaviors to capitalize on these opportunities. Thus, 
proactiveness appears to represent the first link in the hierarchical relationship between the dimensions of entrepreneurial orientation." Our conceptualization and results support this role of proactiveness as a driver of risk taking.

Our paper differs from (and extends) Tang et al. (2009) by (i) identifying how the dimensions of EO relate to performance rather than just other dimensions of EO, and (ii) considering a broader array of interrelations between the dimensions of EO. For example, while Tang et al. (2009) highlight that proactiveness plays a key role in driving other components of EO, we show that risk taking plays a key role in driving performance. By bringing performance into the picture, we identify additional relationships between the dimensions of EO that were not analyzed by Tang et al. (2009), e.g., that innovativeness plays a moderating role in the risk taking-performance relationship.

Finally, although we have focused on the EO-performance relationship, EO is also related to other outcomes of the entrepreneurship process. For example, Wiklund and Shepherd (2011) find a positive relationship between EO and the variance of performance. Our analysis suggests that disaggregating the dimensions of EO may be a fruitful way to better understand the underlying mechanisms underpinning relationships between EO and other variables of interest.

Our empirical analysis also has some limitations. First, we identify the relationships of interest using cross-sectional variation. Given the measures of performance and dimensions of EO are self-reported our estimates may be inflated as a result of common method variance. We do not, however, expect common method variance to have a large influence on our results given previous studies using a very similar setting including self-reported measures find no effects of common method variance (e.g., Wiklund and Shepherd, 2003, 2005; Kreiser et al., 2013). Furthermore, types of questions in this study regarding performance are not those that are typically mis-reported (i.e., the percent increase in profitability as opposed to actual revenue numbers). Finally, the meta-analysis by Rauch et al. (2009) indicates that the use of archival performance data produces EO-performance 
estimates of similar magnitude as self-reported performance measures suggesting common method variance does not have a strong influence in this research setting.

\section{Conclusions}

This article helps understand why EO is positively related to performance. The relationship arises primarily because constructive risk taking, a component of $\mathrm{EO}$, is rewarded with better average performance. The rewards to risk taking tend to be higher when accompanied by a higher level of innovativeness. A proactive approach to entrepreneurship involves risk taking and therefore indirectly leads to higher performance, in proportion to the risk involved. Consequently, all three dimensions of EO (risk taking, proactiveness, and innovativeness) contribute to performance, but for different reasons.

Our analysis does not question the validity of the EO construct, in particular as a predictor of firm performance. Rather, our contribution lies in helping understand the mechanisms that underpin the EO-performance relationship and providing a more nuanced model of how risk taking, proactiveness, and innovativeness combine to drive performance. Our findings also suggest that innovativeness and proactiveness are deliberate strategies within firms as opposed to traits that an entrepreneur either has or does not have, consistent with the original conceptualizations of EO as a firm-level attribute. These findings contribute to the debate about whether EO should be conceptualized at the firm or individual level.

Our analysis suggests a number of directions for future research. First, our conceptualization implies that any aspect of orientation/strategy that is related to performance obtains this association via its relationship with risk taking. While we find support for this notion within the dimensions of EO, many other aspects of orientation/strategy could be used to examine the generality of this notion. Second, our empirical results imply that innovativeness positively influences the type of risks taken 
by entrepreneurs, whereas proactiveness tends to influence the level of risk taking. It would be valuable to explore how this tendency comes about, for example, do innovative firms take actions to offset the risks in being innovative? Third, there is considerable scope to increase understanding of the types of risk that are and are not associated with increasing performance, i.e., characterize what constitutes constructive vs non-constructive ("hazardous") risk taking. Our results suggest innovativeness is one of the factors associated with constructive risk taking. This line of research might look for other factors that moderate the relationship between risk taking and performance, or might explore systematic versus idiosyncratic risk in the entrepreneurship context. Fourth, it would be useful to examine how the interactions between the components of EO depend on contextual factors, in particular, the degree of competition and the degree of information about opportunities. Fifth, the interactions between the dimensions of EO in driving performance provide a potential explanation for nonlinearity in the EO-performance relationship, but a deeper analysis of this issue would benefit the EO-performance literature. 


\section{References}

Andersen, J. (2010). A critical examination of EO-performance relationship. International Journal of Entrepreneurial Behaviour and Research, 16, 309-328.

Anderson, B.S., Covin, J.G., \& Slevin, D.P. (2009). Understanding the relationship between entrepreneurial orientation and strategic learning capability: An empirical investigation. Strategic Entrepreneurship Journal, 3, 2018-2240.

Anderson, B.S., Kreiser, P.M., Kuratko, D.F., Hornsby, J.S., \& Eshima, Y. (2015). Reconceptualizing entrepreneurial orientation. Strategic Management Journal, 36, 15791596.

Anderson, B.S., \& Eshima, Y. (2013). The influence of firm age and intangible resources on the relationship between entrepreneurial orientation and firm growth among Japanese SMEs. Journal of Business Venturing, 28, 413-429.

Arnold, H.J. (1982). Moderator variables: A clarification of conceptual, analytic, and psychometric issues. Organizational behavior and human performance, 29, 143-174.

Baker, W.E., \& Sinkula, J.M. (2009). The complementary effects of market orientation and entrepreneurial orientation on profitability in small business. Journal of Small Business Management, 47, 443-464.

Becherer, R.C., \& Maurer, J.G. (1997). The moderating effect of environmental variables on the entrepreneurial and marketing orientation of entrepreneur-led firms. Entrepreneurship Theory and Practice, 22, 47-58.

Begley, T.M., \& Boyd, D.P. (1987). Psychological characteristics associated with performance in entrepreneurial firms and smaller businesses. Journal of Business Venturing, 2, 79-93.

Bewley T.F. (2001). Market innovation and entrepreneurship: A Knightian view. In: Debreu G., Neuefeind W., \& Trockel W. (eds) Economics Essays. Springer, Berlin.

Boso, N., Story, V.M., \& Cadogan, J.W. (2013). Entrepreneurial orientation, market orientation, network ties, and performance: Study of entrepreneurial firms in a developing economy. Journal of Business Venturing, 28, 708-727.

Brouthers, K.D., Nakos, G., \& Dimitratos, P. (2014). SME entrepreneurial orientation, international performance, and the moderating role of strategic alliances. Entrepreneurship Theory and Practice, 39, 1161-1187.

Camerer, C., \& Weber, M. (1992). Recent developments in modelling preferences: Uncertainty and ambiguity. Journal of Risk and Uncertainty, 5, 325-370.

Casillas, J.C., \& Moreno, A.M. (2010). The relationship between entrepreneurial orientation and growth: The moderating role of family involvement. Entrepreneurship and Regional Development, 22, 265-291.

Chaston, I., \& Sadler-Smith, E. (2012). Entrepreneurial cognition, entrepreneurial orientation and firm capability in the creative industries. British Journal of Management, 23, 415-432.

Chen, Z., \& Epstein, L.G. (2002). Ambiguity, risk, and asset returns in continuous time. Econometrica, 70, 1403-1443.

Chirico, F., Sirmon, D.F., Sciascia, S., \& Mazzola, P. (2011). Resource orchestration in family forms: investigating how entrepreneurial orientation, generational involvement and participation strategy affect performance. Strategic Entrepreneurship Journal, 5, 307-326.

Cho, H.J., \& Pucik, V. (2005). Relationship between innovativeness, quality, growth, profitability, and market value. Strategic Management Journal, 26, 555-575.

Covin, J.G., Slevin, D.P., \& Heeley, M.B. (2000). Pioneers and followers: competitive tactics, environment, and firm growth. Journal of Business Venturing, 15, 175-210.

Covin, J.G., Green, K.M., \& Slevin, D.P. (2006). Strategic process effects on the entrepreneurial orientation-sales growth rate relationship. Entrepreneurship Theory and Practice, 30, 57-81. 
Covin J.G., \& Lumpkin G.T. (2011). Entrepreneurial orientation theory and research: Reflections on a needed construct. Entrepreneurship Theory and Practice, 35, 855-872.

Covin, J.G., \& Miller, D. (2014). International entrepreneurial orientation: Conceptual considerations, research themes, measurement issues, and future research directions. Entrepreneurship Theory and Practice 38, 11-44.

Covin, J.G., \& Slevin, D.P. (1989). Strategic management of small firms in hostile and benign environments. Strategic Management Journal, 10, 75-87.

Covin, J.G., \& Slevin, D.P. (1991). A conceptual model of entrepreneurship as firm behavior. Entrepreneurship Theory and Practice, 16, 7-25.

Covin, J.G., \& Wales, W.J. (2012). The measurement of entrepreneurial orientation. Entrepreneurship Theory and Practice, 36, 677-702.

Dada, O., \& Watson, A. (2013). Entrepreneurial orientation and the franchise system: Organisational antecedents and performance outcomes, European Journal of Marketing, 47, 790-812.

De Clercq, D., Dimov, D., \& Thongpapanl, N. (2010). The moderating impact of internal social exchange processes on the entrepreneurial orientation-performance relationship. Journal of Business Venturing, 25, 87-103.

Deligianni, I., Dimitratos, P., Petrou, A., \& Aharoni, Y. (2016). Entrepreneurial orientation and international performance: The moderating effect of decision-making rationality. Journal of Small Business Management, 54, 462-480.

Deschryvere, M. (2014). R\&D, firm growth and the role of innovation persistence: An analysis of Finnish SMEs and large firms. Small Business Economics, 43, 767-785.

Drucker, P. (1985). Innovation and entrepreneurship. Practice and principles. New York: Harper and Row.

Edmond, V., \& Wiklund, J. (2010). The historic roots of entrepreneurial orientation research. In H. Landstrom \& F. Lohrke (Eds.), The historical foundations of entrepreneurship research (pp. 142-160). Cheltenham, U.K.: Edward Elgar Publishers.

Ellsberg, D. (1961). Risk, ambiguity, and the savage axioms. Quarterly Journal of Economics, 75, 643-669.

Engelen, A., Gupta, V., Strenger, L., \& Brettel, M. (2015). Entrepreneurial orientation, firm performance, and the moderating role of transformational leadership behaviors. Journal of Management, 41, 1069-1097.

Engelen, A., Kube, H., Schmidt, S. \& Flatten, T.C. (2014). Entrepreneurial orientation in turbulent environments: The moderating role of absorptive capacity. Research Policy, 43, 1353-1369.

Epstein, L.G., \& Wang, T. (1994). Intertemporal asset pricing under Knightian uncertainty. Econometrica, 62, 283-322.

Epstein, L.G., \& Schneider, M. (2010). Ambiguity and asset markets. Annual Review of Financial Economics, 2, 315-346.

Fama, E. (1965). The behavior of stock market prices. Journal of Business, 38, 34-105.

George, B.A., \& Marino, L. (2011). The epistemology of entrepreneurial orientation: conceptual formation, modeling, and operationalization. Entrepreneurship Theory and Practice, 35, 9891024.

Gilboa, I., Postlewaite, A.W., \& Schmeidler, D. (2008). Probability and uncertainty in economic modeling. Journal of Economic Perspectives, 22, 173-188.

Gilboa, I. (2009). Theory of Decision under Uncertainty, Cambridge University Press, Cambridge.

Graham, J.R., \& Harvey, C.R. (2001). The theory and practice of corporate finance: evidence from the field. Journal of Financial Economics, 60, 187-243.

Griffith R., Huergo, E., Mairesse, J., \& Peters, B. (2006). Innovation and productivity across four European countries. Oxford Review Economic Policy, 22, 483-498. 
Guidolin, M., \& Rinaldi, F. (2013). Ambiguity in asset pricing and portfolio choice: A review of the literature. Theory and Decision, 74, 183-217.

Gupta, V.K., \& Batra, S. (2016). Entrepreneurial orientation and firm performance in Indian SMEs: Universal and contingency perspectives. International Small Business Journal, 34, 660-682.

Gupta, V.K., \& Wales, W.J. (2017). Assessing organisational performance within entrepreneurial orientation research: Where have we been and where can we go from here? Journal of Entrepreneurship, 26, 51-76.

Hebert, R., \& Link, A. (1988). The Entrepreneur. Mainstream views and radical critiques. Second edition. New York: Praeger Publishers.

Hornsby, J.S., Kuratko, D.F., Shepherd, D.A., \& Bott, J.P. (2009). Managers' corporate entrepreneurial actions: examining perception and position. Journal of Business Venturing, 24, 236-247.

Hughes, M., \& Morgan, R.E. (2007). Deconstructing the relationship between entrepreneurial orientation and business performance at the embryonic stage of firm growth. Industrial Marketing Management, 36, 651-661.

Jiang, X., Yang, Y., Pei, Y.-L., \& Wang, G. (2016). Entrepreneurial orientation, strategic alliances, and firm performance: Inside the black box. Long Range Planning, 49, 103-116.

Keh, H.T., Nguyen, T.T.M., \& Ng, H.P. (2007). The effects of entrepreneurial orientation and marketing information on the performance of SMEs. Journal of Business Venturing, 22, 592611.

Keynes, J.M. (1921). A Treatise on Probability, Macmillan and Co., London.

Khilstrom, R., \& Laffont, J. (1979). A general equilibrium entrepreneurial theory of firm formation based on risk aversion. Journal of Political Economy, 87, 719-748.

Knight, F. (1921). Risk, Uncertainty and Profit, Houghton Mifflin, Boston/New York.

Kollmann, T., \& Stöckmann, C. (2012). Filling the entrepreneurial orientation-performance gap: The mediating effects of exploratory and exploitative innovations. Entrepreneurship Theory and Practice, 46, 1002-1022.

Kraus, S. (2013). The role of entrepreneurial orientation in service firms: Empirical evidence from Austria. Service Industries Journal, 33, 427-444.

Kreiser, P.M., Marino, L.D., Kuratko, D.F., \& Weaver, K.M. (2013). Disaggregating entrepreneurial orientation: The non-linear impact of innovativeness, proactiveness and risk-taking on SME performance. Small Business Economics, 40, 273-291.

Lechner, C., \& Gudmundsson, S.V. (2014). Entrepreneurial orientation, firm strategy and small firm performance. International Small Business Journal, 32, 36-60.

Li, Y-H., Huang, J-W., \& Tsai, M-T. (2009). Entrepreneurial orientation and firm performance: The role of knowledge creation process. Industrial Marketing Management, 38, 440-449.

Lintner, J. (1965). The valuation of risk assets and the selection of risky investments in stock portfolios and capital budgets. Review of Economics and Statistics, 47, 13-37.

Linton, G. (2016). Entrepreneurial orientation. Reflections from a contingency perspective. Örebro Studies in Business Dissertations 9. Örebro, Sweden: Örebro University.

Linton, G., \& Kask, J. (2017). Configurations of entrepreneurial orientation and competitive strategy for high performance. Journal of Business Research, 70, 168-176.

Lisboa, A., Skarmeas, D., \& Saridakis, C. (2016). Entrepreneurial orientation pathways to performance: A fuzzy-set analysis. Journal of Business Research, 69, 1319-1324.

Lisboa, A., Skarmeas, D., \& Lages, C. (2011). Entrepreneurial orientation, exploitative and explorative capabilities, and performance outcomes in export markets: A resource-based approach. Industrial Marketing Management, 40, 1274-1284. 
Lomberg, C., Urbig, Stöckmann, C., Marino, L.D., \& Dickson, P.H. (2017). Entrepreneurial orientation: The dimensions' shared effects in explaining firm performance. Entrepreneurship Theory and Practice, 41, 973-998.

Lumpkin, G.T. (1998). Do new entrant firms have an entrepreneurial orientation? Paper presented at the Academy of Management annual meeting, San Diego, CA.

Lumpkin, G.T., Cogliser, C.C., \& Schneider, D.R. (2009). Understanding and measuring autonomy: An entrepreneurial orientation perspective. Entrepreneurship Theory and Practice, 33, 47-69.

Lumpkin, G.T., \& Dess, G.G. (2001). Linking two dimensions of entrepreneurial orientation to firm performance: The role of environment and industry life cycle. Journal of Business Venturing, $16,429-451$.

Lumpkin, G.T., \& Dess, G.G. (1996). Clarifying the entrepreneurial orientation construct and linking it to performance. Academy of Management Review, 21, 135-172.

Markowitz, H. (1952). Portfolio selection. Journal of Finance, 7, 77-91.

Martin, S.L., \& Javalgi, R.G. (2016). Entrepreneurial orientation, marketing capabilities and performance: The moderating role of competitive Intensity on Latin American International new ventures. Journal of Business Research, 69, 2040-2051.

McGee, J.E., \& Peterson, M. (2017). The long-term impact of entrepreneurial self-efficacy and entrepreneurial orientation on venture performance. Journal of Small Business Management (forthcoming), doi: 10.1111/jsbm.12324

McMullen, J.S. \& Shepherd, D.A. (2006). Entrepreneurial action and the role of uncertainty in the theory of the entrepreneur. Academy of Management Review, 31, 132-152.

Messersmith, J.G., \& Wales, W.J. (2013). Entrepreneurial orientation and performance in young firms: The role of human resource management. International Small Business Journal, 31, $115-136$.

Mickiewicz, T., Sauka, A., \& Stephan, U. (2016). On the compatibility of benevolence and selfinterest: Philanthropy and entrepreneurial orientation. International Small Business Journal, 34, 303-328.

Miller, D. (2011). Miller 1983 revisited: a reflection on EO research and some suggestions for the future. Entrepreneurship Theory and Practice, 35, 873-894.

Miller, D. (1983). The correlates of entrepreneurship in three types of firms. Management Science, 29, 770-791.

Miller, D., \& Breton-Miller, I.L. (2011). Governance, social identity, and entrepreneurial orientation in closely held public companies. Entrepreneurship Theory and Practice, 35, 1051-1076.

Miller, D., \& Friesen, P.H. (1978). Archetypes of strategy formulation. Management science, 24, 921-933.

Moreno, A.M., \& Casillas, J.C. (2008). Entrepreneurial orientation and growth of SMEs: A causal model. Entrepreneurship Theory and Practice, 32, 507-528.

Naldi, L., Nordqvist, M., Sjöberg, K., \& Wiklund, J. (2007). Entrepreneurial orientation, risk taking, and performance in family firms. Family Business Review, 20, 33-47.

Núñez-Pomar, J., Prado-Gascó, V., Sanz, J.A., Hervás, J.C., \& Morenoa, F.C. (2016). Does size matter? Entrepreneurial orientation and performance in Spanish sports firms. Journal of Business Research, 69, 5336-5341.

Pearce, J. A., Fritz, D.A., \& Davis, P.S. (2010). Entrepreneurial orientation and the performance of religion congregations as predicted by rational choice theory. Entrepreneurship Theory and Practice, 34, 219-248.

Poon, J.M.L., Ainuddin, R.A., \& Junit, S.H. (2006). Effects of self-concept traits and entrepreneurial orientation on firm performance. International Small Business Journal, 24, 61-82. 
Preacher, K.J., \& Hayes, A.F. (2004). SPSS and SAS procedures for estimating indirect effects in simple mediation models. Behavior Research Methods, Instruments and Computers, 36, $717-$ 731.

Raisch, S., \& Birkinshaw, J. (2008) Organizational ambidexterity: Antecedents, outcomes, and moderators. Journal of Management, 34, 375-409.

Rauch, A., Wiklund, J., Lumpkin, G.T., \& Frese, M. (2009). Entrepreneurial orientation and business performance: An assessment of past research and suggestions for the future. Entrepreneurship Theory and Practice, 33, 761-787.

Rauch, A., Wiklund, J., Frese, M., \& Lumpkin, G.T. (2004). Entrepreneurial orientation and business performance: Cumulative empirical evidence. In W.D. Bygrave, C.G. Brush, M.L.P Davidsson, G.D. Meyer, J. Fiet, J. Sohl, P.G. Greene, A. Zacharakis, \& R.T. Harrison (Eds.), Frontiers of entrepreneurship research. Wellesley, MA: Babson College.

Real, J.C., Roldán, J.L., \& Leal, A. (2014). From entrepreneurial orientation and learning orientation to business performance: Analysing the mediating role of organizational learning and the moderating effects of organizational size. British Journal of Management, 25, 186-208.

Rieger, M.O., Wang, M., \& Hens, T. (2015). Risk preferences around the world, Management Science, 61, 637-648.

Rigtering, J.P.C., Eggers, F., Kraus, S., \& Chang, M-L. (2017). Entrepreneurial orientation, strategic planning and firm performance: the impact of national cultures, European Journal of International Management, 11, 301-324.

Rosenbusch, N., Brinkmann, J., \& Bausch, A. (2011). Is innovation always beneficial? A metaanalysis of the relationship between innovation and performance in SMEs. Journal of Business Venturing, 26, 441-457.

Rosenbusch, N., Rauch, A., \& Bausch, A. (2013). The mediating role of entrepreneurial orientation in the task environment-performance relationship: A meta-analysis. Journal of Management, $39,633-659$.

Runyan, R., Ge, B., Dong, B., \& Swinney, J. (2012). Entrepreneurial orientation in cross-cultural research: assessing measurement invariance in the construct. Entrepreneurship Theory and Practice, 36, 819-836.

Saeed, S., Yousafzai, S.Y., \& Engelen, A. (2014). On cultural and macroeconomic contingencies of the entrepreneurial orientation-performance relationship. Entrepreneurship Theory and Practice, 38, 255-290.

Schepers, J., Voordeckers, W., Steijvers, T., \& Laveren, E. (2014). The entrepreneurial orientationperformance relationship in private family firms: The moderating role of socioemotional wealth. Small Business Economics, 43, 39-55.

Schere, J.L. (1982). Tolerance for ambiguity as a discriminating variable between entrepreneurs and managers. Proceedings of the Academy of Management, 1, 404-408.

Schumpeter, J. (1934). The Theory of Economic Development. Cambridge, MA: Harvard University Press.

Semrau, T., Ambos, T., \& Kraus, S. (2016). Entrepreneurial orientation and SME performance across societal cultures: An international study. Journal of Business Research, 69, 1928-1932.

Shane S. (2003). A General Theory of Entrepreneurship, Edward Elgar, Northampton, MA.

Shane, S., \& Venkataraman, S. (2000). The promise of entrepreneurship as a field of research. Academy of Management Review, 25, 217-226.

Sharpe, W. (1964). Capital asset prices: A theory of market equilibrium under conditions of risk. Journal of Finance, 19, 425-442.

Smith, K., \& Cao, Q. (2007). An entrepreneurial perspective on the firm-environment relationship. Strategic Entrepreneurship Journal, 1, 329-344. 
Soininen, J., Martikainen, M., Puumalainen, K., \& Kylaheiko, K. (2012). Entrepreneurial orientation: Growth and profitability of Finnish small- and medium-sized enterprises. International Journal of Production Economics, 140, 614-621.

Stam, W., \& Elfring, T. (2008). Entrepreneurial orientation and new venture performance: The moderating role of intra- and extra-industry social capital. Academy of Management Journal, 51, 97-111.

Stenholm, P., Pukkinen, T. \& Heinonen, J. (2016). Firm growth in family businesses-The role of entrepreneurial orientation and the entrepreneurial activity. Journal of Small Business Management, 54, 697-713.

Su, Z., Xie, E., \& Wang, D. (2015). Entrepreneurial orientation, managerial networking, and new venture performance in China. Journal of Small Business Management, 53, 228-248.

Su, Z., Xie, E., \& Li, Y. (2011). Entrepreneurial orientation and firm performance in new ventures and established firms. Journal of Small Business Management, 49, 558-577.

Tajjedini, K., Elg., U., \& Trueman, M. (2013). Efficiency and effectiveness of small retailers: The role of customer and entrepreneurial orientation. Journal of Retailing and Consumers Services, 20, 453-462.

Tang, Z., Kreiser, P.M., Marino, L., Dickson, P., \& Weaver, K.M. (2009) A hierarchical perspective of the dimensions of entrepreneurial orientation. International Entrepreneurship and Management Journal, 5,181-201.

Tang, J., Tang, Z., Marino, L.D., Zhang, Y., \& Li, Q. (2008). Exploring an inverted U-shape relationship between entrepreneurial orientation and performance in Chinese ventures. Entrepreneurship Theory and Practice, 32, 219-239.

Tang, Z., \& Tang, J. (2012). Entrepreneurial orientation and SME performance in China's changing environment: The moderating effects of strategies. Asia Pacific Journal of Management, 29, 409-432.

Terziovski, M. (2010). Innovation practice and its performance implications in small and medium enterprises (SMEs) in the manufacturing sector: a resource-based view. Strategic Management Journal, 31, 892-902.

Van Doorn, S., Jansen, J.J.P., Van den Bosch, F.A.J., \& Volberda, H.W. (2013). Entrepreneurial orientation and firm performance: Drawing attention to the senior team. Journal of Product Innovation Management, 30, 821-836.

Vega-Vázquez, M., Cossío-Silva, F.-J., \& Revilla-Camacho, M.-Á. (2016). Entrepreneurial orientation-hotel performance: Has market orientation anything to say? Journal of Business Research, 69, 5089-5094.

Venkatraman, N. (1989). Strategic orientation of business enterprises: The construct dimensionality, and measurement. Management Science, 35, 942-962.

Wakker, P. (2010). Prospect Theory for Risk and Ambiguity, Cambridge University Press, Cambridge.

Wales, W.J. (2016). Entrepreneurial orientation: A review and synthesis of promising research directions. International Small Business Journal, 34, 3-15.

Wales, W.J., Gupta, V.K., \& Mousa, F.-T. (2013). Empirical research on entrepreneurial orientation: an assessment and suggestions for future research. International Small Business Journal, 31, 357-383.

Wales, W.J., Patel, P.C., Parida, V., \& Kreiser, P.M. (2013a). Non-linear effects of entrepreneurial orientation on small firm performance: The moderating resource of resource orchestration capabilities. Strategic Entrepreneurship Journal, 7, 93-121.

Walls, M.R., \& Dyer, J.S. (1996). Risk propensity and firm performance: A study of the petroleum exploration industry. Management Science, 42, 1004-1021. 
Walter, A., Auer, M., \& Ritter, T. (2006). The impact of network capabilities and entrepreneurial orientation on university spin-off performance. Journal of Business Venturing, 21, 541-567.

Wang, C.L., Thornhill, S., \& DeCastro, J.O. (2017). Entrepreneurial orientation, legitimation, and new venture performance. Strategic Entrepreneurship Journal (forthcoming). DOI: $10.1002 /$ sej.1246.

Wang, C.L. (2008). Entrepreneurial orientation, learning orientation, and firm performance. Entrepreneurship Theory and Practice, 32, 635-656.

Weber, M. \& Camerer, C. (1987). Recent developments in modelling preferences under risk. Operations Research Spektrum, 9, 129-151.

Wheelwright, S.C., \& Clark, K.B. (1992). Revolutionizing Product Development-Quantum Leaps in Speed, Efficiency, and Quality. New York: The Free Press.

Wiklund, J., Patzelt, H., \& Shepherd, D. (2009). Building an integrative model of small business growth, Small Business Economics, 32, 351-374.

Wiklund, J., \& Shepherd, D.A. (2011). Where to from here? EO as experimentation, failure, and distribution of outcomes. Entrepreneurship Theory and Practice, 35, 925-946.

Wiklund, J., \& Shepherd, D.A. (2005). Entrepreneurial orientation and small business performance: a configurational approach. Journal of Business Venturing, 20, 71-91.

Wiklund, J., \& Shepherd, D.A. (2003). Knowledge-based resources, entrepreneurial orientation, and the performance of small and medium-sized businesses. Strategic Management Journal, 24, $1307-1314$.

Wiklund, J. (1999). The sustainability of the entrepreneurial orientation-performance relationship. Entrepreneurship Theory and Practice, 24, 37-48.

Zahra, S.A., Jennings, D.F., \& Kuratko, D.F. (1999). The antecedents and consequences of firmlevel entrepreneurship: The state of the field. Entrepreneurship Theory and Practice, 24, 4565.

Zhao, Y., Li, Y., Lee, S.H., \& Chen L.B. (2009). Entrepreneurial orientation, organizational learning, and performance: Evidence from China. Entrepreneurship Theory and Practice, 35, 293-317.

Yasuda, T. (2005). Firm growth, size, age and behavior in Japanese manufacturing. Small Business Economics, 24, 1-15. 
Table 1

Sample composition

This table reports the number of firms in the sample, by sector and country.

\begin{tabular}{lcccc}
\hline & Estonia & Latvia & Lithuania & Sum \\
\hline Manufacturing & 44 & 73 & 47 & 164 \\
Wholesale & 46 & 84 & 53 & 183 \\
Retail & 22 & 64 & 40 & 126 \\
Services & 149 & 151 & 42 & 342 \\
Construction & 77 & 35 & 17 & 129 \\
Other & 38 & 24 & 14 & 76 \\
& & & & \\
Sum & 376 & 431 & 213 & 1,020 \\
\hline
\end{tabular}




\section{Table 2}

Descriptive statistics and correlations between variables

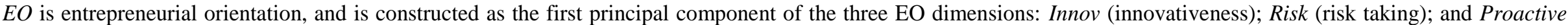

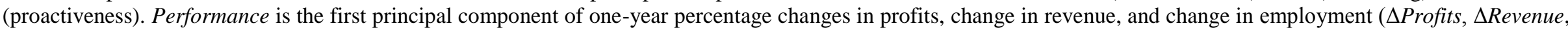

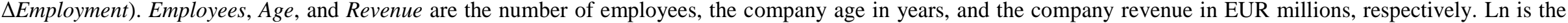
natural logarithm. The correlation p-values are reported in parentheses below the corresponding correlation.

\begin{tabular}{|c|c|c|c|c|c|c|c|c|c|c|c|c|}
\hline & $\mathrm{EO}$ & Innov & Risk & Proactive & Performance & $\Delta$ Profits & $\Delta$ Revenue & $\begin{array}{c}\Delta \text { Employ- } \\
\text { ment }\end{array}$ & Employees & $\begin{array}{c}\text { Ln(Employ- } \\
\text { ees })\end{array}$ & Age & Revenue \\
\hline Mean & 0.00 & 0.00 & -0.01 & -0.01 & 0.00 & 18.82 & 9.47 & -2.81 & 48.07 & 2.59 & 11.57 & 3.97 \\
\hline Std. deviation & 0.99 & 0.99 & 1.00 & 0.98 & 1.00 & 80.67 & 43.35 & 20.95 & 222.29 & 1.37 & 5.77 & 15.22 \\
\hline \multicolumn{13}{|l|}{ Correlations: } \\
\hline $\mathrm{EO}$ & $\begin{array}{c}1 \\
(0.000)\end{array}$ & & & & & & & & & & & \\
\hline Innov & $\begin{array}{c}0.70 \\
(0.000)\end{array}$ & $\begin{array}{c}1 \\
(0.000)\end{array}$ & & & & & & & & & & \\
\hline Risk & $\begin{array}{c}0.72 \\
(0.000)\end{array}$ & $\begin{array}{c}0.21 \\
(0.000)\end{array}$ & $\begin{array}{c}1 \\
(0.000)\end{array}$ & & & & & & & & & \\
\hline Proactive & $\begin{array}{c}0.84 \\
(0.000)\end{array}$ & $\begin{array}{c}0.42 \\
(0.000)\end{array}$ & $\begin{array}{c}0.44 \\
(0.000)\end{array}$ & $\begin{array}{c}1 \\
(0.000)\end{array}$ & & & & & & & & \\
\hline Performance & $\begin{array}{c}0.18 \\
(0.000)\end{array}$ & $\begin{array}{c}0.12 \\
(0.000)\end{array}$ & $\begin{array}{c}0.16 \\
(0.000)\end{array}$ & $\begin{array}{c}0.15 \\
(0.000)\end{array}$ & $\begin{array}{c}1 \\
(0.000)\end{array}$ & & & & & & & \\
\hline$\Delta$ Profits & $\begin{array}{c}0.13 \\
(0.000)\end{array}$ & $\begin{array}{c}0.09 \\
(0.005)\end{array}$ & $\begin{array}{c}0.06 \\
(0.052)\end{array}$ & $\begin{array}{c}0.14 \\
(0.000)\end{array}$ & $\begin{array}{c}0.77 \\
(0.000)\end{array}$ & $\begin{array}{c}1 \\
(0.000)\end{array}$ & & & & & & \\
\hline$\Delta$ Revenue & $\begin{array}{c}0.17 \\
(0.000)\end{array}$ & $\begin{array}{c}0.11 \\
(0.000)\end{array}$ & $\begin{array}{c}0.14 \\
(0.000)\end{array}$ & $\begin{array}{c}0.15 \\
(0.000)\end{array}$ & $\begin{array}{c}0.89 \\
(0.000)\end{array}$ & $\begin{array}{c}0.58 \\
(0.000)\end{array}$ & $\begin{array}{c}1 \\
(0.000)\end{array}$ & & & & & \\
\hline$\Delta$ Employment & $\begin{array}{c}0.14 \\
(0.000)\end{array}$ & $\begin{array}{c}0.09 \\
(0.003)\end{array}$ & $\begin{array}{c}0.13 \\
(0.000)\end{array}$ & $\begin{array}{c}0.07 \\
(0.026)\end{array}$ & $\begin{array}{c}0.73 \\
(0.000)\end{array}$ & $\begin{array}{c}0.28 \\
(0.000)\end{array}$ & $\begin{array}{c}0.52 \\
(0.000)\end{array}$ & $\begin{array}{c}1 \\
(0.000)\end{array}$ & & & & \\
\hline Employees & $\begin{array}{c}0.13 \\
(0.000)\end{array}$ & $\begin{array}{c}0.07 \\
(0.022)\end{array}$ & $\begin{array}{c}0.04 \\
(0.131)\end{array}$ & $\begin{array}{c}0.16 \\
(0.000)\end{array}$ & $\begin{array}{c}0.03 \\
(0.430)\end{array}$ & $\begin{array}{c}0.03 \\
(0.302)\end{array}$ & $\begin{array}{c}0.02 \\
(0.630)\end{array}$ & $\begin{array}{c}0.00 \\
(0.934)\end{array}$ & $\begin{array}{c}1 \\
(0.000)\end{array}$ & & & \\
\hline Ln(Employees) & $\begin{array}{c}0.20 \\
(0.000)\end{array}$ & $\begin{array}{c}0.18 \\
(0.000)\end{array}$ & $\begin{array}{c}0.07 \\
(0.017)\end{array}$ & $\begin{array}{c}0.23 \\
(0.000)\end{array}$ & $\begin{array}{c}0.11 \\
(0.002)\end{array}$ & $\begin{array}{c}0.13 \\
(0.000)\end{array}$ & $\begin{array}{c}0.12 \\
(0.000)\end{array}$ & $\begin{array}{c}0.02 \\
(0.532)\end{array}$ & $\begin{array}{c}0.47 \\
(0.000)\end{array}$ & $\begin{array}{c}1 \\
(0.000)\end{array}$ & & \\
\hline Age & $\begin{array}{c}-0.06 \\
(0.068)\end{array}$ & $\begin{array}{c}0.00 \\
(0.955)\end{array}$ & $\begin{array}{c}-0.07 \\
(0.024)\end{array}$ & $\begin{array}{c}0.00 \\
(0.877)\end{array}$ & $\begin{array}{c}-0.16 \\
(0.000)\end{array}$ & $\begin{array}{c}-0.05 \\
(0.115)\end{array}$ & $\begin{array}{c}-0.15 \\
(0.000)\end{array}$ & $\begin{array}{c}-0.13 \\
(0.000)\end{array}$ & $\begin{array}{c}0.16 \\
(0.000)\end{array}$ & $\begin{array}{c}0.38 \\
(0.000)\end{array}$ & $\begin{array}{c}1 \\
(0.000)\end{array}$ & \\
\hline Revenue & $\begin{array}{c}0.06 \\
(0.090)\end{array}$ & $\begin{array}{c}0.05 \\
(0.123)\end{array}$ & $\begin{array}{c}0.01 \\
(0.866)\end{array}$ & $\begin{array}{c}0.10 \\
(0.004)\end{array}$ & $\begin{array}{c}0.01 \\
(0.721)\end{array}$ & $\begin{array}{c}0.00 \\
(0.886)\end{array}$ & $\begin{array}{c}0.02 \\
(0.611)\end{array}$ & $\begin{array}{c}0.00 \\
(0.964)\end{array}$ & $\begin{array}{c}0.53 \\
(0.000)\end{array}$ & $\begin{array}{c}0.36 \\
(0.000)\end{array}$ & $\begin{array}{c}0.12 \\
(0.000)\end{array}$ & $\begin{array}{c}1 \\
(0.000)\end{array}$ \\
\hline
\end{tabular}




\section{Table 3}

\section{Tests of the relationship between firm performance and dimensions of entrepreneurial orientation}

This table reposts coefficients of 10 cross-sectional regressions with the dependent variable indicated at the top of each column. EO is entrepreneurial orientation, and is constructed as the first principal component of the three EO dimensions: Innov (innovativeness); Risk (risk taking); and Proactive (proactiveness). Performance is the first principal component of one-year percentage change in profits, change in revenue, and change in employment. Ln(Employees) and Age are the natural logarithm of the number of employees, and the company age, respectively. $* * *$ and $* * *$ indicate statistical significance at the $10 \%, 5 \%$ and $1 \%$ levels, respectively. T-statistics are reported in parentheses.

\begin{tabular}{|c|c|c|c|c|c|c|c|c|c|c|}
\hline Model & $\begin{array}{c}1 \\
\text { Performance }\end{array}$ & $\begin{array}{c}2 \\
\text { Performance } \\
\end{array}$ & $\begin{array}{c}3 \\
\text { Performance } \\
\end{array}$ & $\begin{array}{c}4 \\
\text { Performance } \\
\end{array}$ & $\begin{array}{c}5 \\
\text { Performance } \\
\end{array}$ & $\begin{array}{c}6 \\
\text { Performance } \\
\end{array}$ & $\begin{array}{c}7 \\
\text { Performance } \\
\end{array}$ & $\begin{array}{c}8 \\
\text { Risk } \\
\end{array}$ & $\begin{array}{c}9 \\
\text { Risk }\end{array}$ & $\begin{array}{c}10 \\
\text { Risk }\end{array}$ \\
\hline EO & $\begin{array}{c}0.134 * * * \\
(3.86)\end{array}$ & & & & & & & & & \\
\hline Innov & & $\begin{array}{l}0.034 \\
(0.88)\end{array}$ & $\begin{array}{l}0.026 \\
(0.69)\end{array}$ & $\begin{array}{l}0.031 \\
(0.78)\end{array}$ & $\begin{array}{c}0.066^{*} \\
(1.85)\end{array}$ & & & $\begin{array}{c}0.201 * * * \\
(6.26)\end{array}$ & & $\begin{array}{l}0.030 \\
(0.89)\end{array}$ \\
\hline Risk & & $\begin{array}{c}0.112 * * * \\
(2.83)\end{array}$ & $\begin{array}{c}0.110 * * * \\
(2.79)\end{array}$ & $\begin{array}{c}0.117 * * * \\
(2.74)\end{array}$ & & $\begin{array}{c}0.136^{* * * *} \\
(4.08)\end{array}$ & & & & \\
\hline Proactive & & $\begin{array}{l}0.032 \\
(0.79)\end{array}$ & $\begin{array}{l}0.033 \\
(0.80)\end{array}$ & $\begin{array}{l}0.035 \\
(0.86)\end{array}$ & & & $\begin{array}{c}0.098 * * * \\
(2.85)\end{array}$ & & $\begin{array}{c}0.460 * * * \\
(15.32)\end{array}$ & $\begin{array}{c}0.450 * * * \\
(13.58)\end{array}$ \\
\hline Risk*Innov & & & $\begin{array}{l}0.053 \\
(1.54)\end{array}$ & $\begin{array}{c}0.057 * \\
(1.65)\end{array}$ & & & & & & \\
\hline Risk*Proactive & & & $\begin{array}{l}0.009 \\
(0.31)\end{array}$ & $\begin{array}{l}0.009 \\
(0.30)\end{array}$ & & & & & & \\
\hline Risk*Innov*Proactive & & & & $\begin{array}{l}-0.013 \\
(-0.48)\end{array}$ & & & & & & \\
\hline Ln(Employees) & $\begin{array}{l}0.102 * * * \\
(3.16)\end{array}$ & $\begin{array}{c}0.106^{* * * *} \\
(3.31)\end{array}$ & $\begin{array}{c}0.107 * * * \\
(3.34)\end{array}$ & $\begin{array}{c}0.106^{* * * *} \\
(3.30)\end{array}$ & $\begin{array}{c}0.109 * * * \\
(3.60)\end{array}$ & $\begin{array}{c}0.107 * * * \\
(3.57)\end{array}$ & $\begin{array}{c}0.112 * * * \\
(3.48)\end{array}$ & $\begin{array}{c}0.093 * * * \\
(3.40)\end{array}$ & $\begin{array}{l}0.014 \\
(0.50)\end{array}$ & $\begin{array}{l}0.014 \\
(0.49)\end{array}$ \\
\hline Age & $\begin{array}{c}-0.034 * * * \\
(-5.09)\end{array}$ & $\begin{array}{c}-0.035^{* * *} \\
(-5.10)\end{array}$ & $\begin{array}{c}-0.035 * * * \\
(-5.17)\end{array}$ & $\begin{array}{c}-0.035 * * * \\
(-5.15)\end{array}$ & $\begin{array}{c}-0.038 * * * \\
(-5.61)\end{array}$ & $\begin{array}{c}-0.037 * * * \\
(-5.62)\end{array}$ & $\begin{array}{c}-0.037 * * * \\
(-5.47)\end{array}$ & $\begin{array}{c}-0.018 * * * \\
(-3.24)\end{array}$ & $\begin{array}{c}-0.015 * * * \\
(-2.81)\end{array}$ & $\begin{array}{c}-0.016 * * * \\
(-2.85)\end{array}$ \\
\hline Country & Yes & Yes & Yes & Yes & Yes & Yes & Yes & Yes & Yes & Yes \\
\hline Sector & Yes & Yes & Yes & Yes & Yes & Yes & Yes & Yes & Yes & Yes \\
\hline Adj. R-squared & 0.107 & 0.110 & 0.114 & 0.114 & 0.107 & 0.121 & 0.099 & 0.068 & 0.215 & 0.221 \\
\hline
\end{tabular}




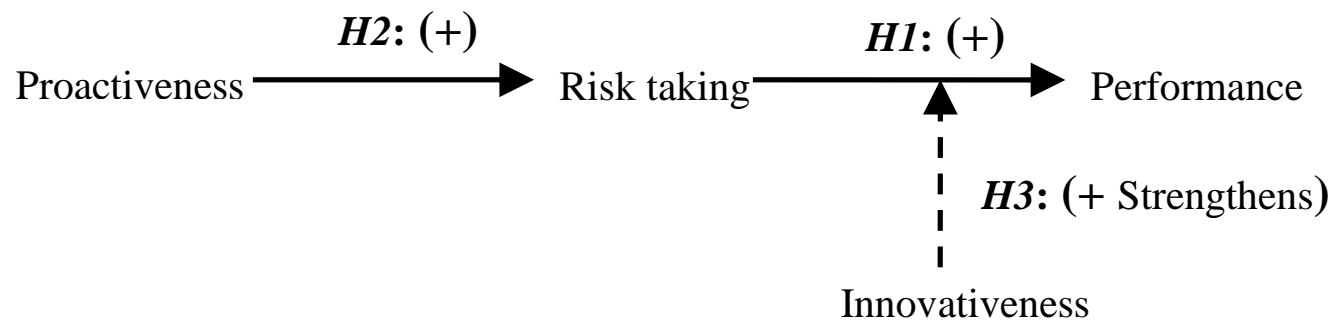

Figure 1. Schematic illustration of hypothesized direct and indirect relationships between the dimensions of EO and performance.

The thick solid line indicates a direct positive effect of risk taking on performance $(H 1)$, the thin solid line indicates the positive, indirect mediating effect of proactiveness $(H 2)$, and the dashed line indicates the positive moderating effect of innovativeness $(H 3)$, which strengthens the risk-performance relationship. 


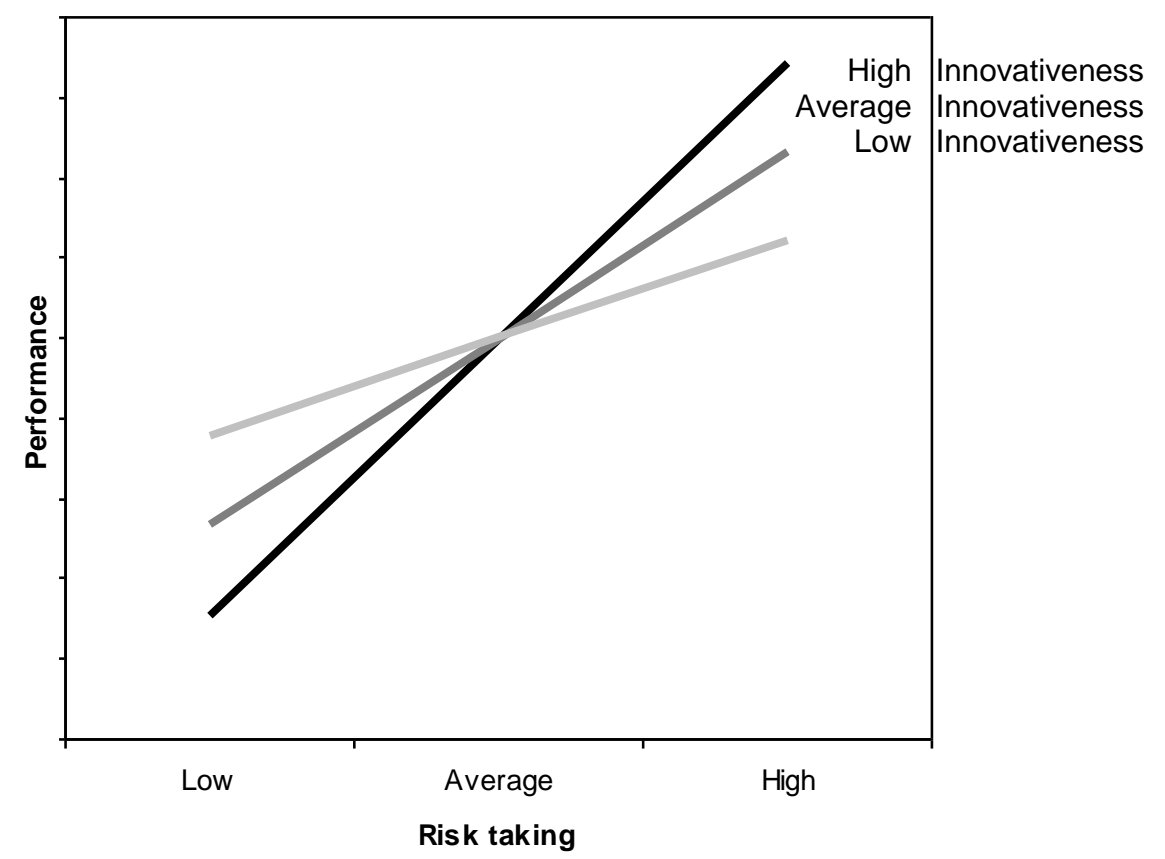

Figure 2. Relationship between risk taking and performance for different levels of innovativeness.

The linear relationships in the figure are calculated using the coefficient estimates from regressions and varying the level of risk taking from low (one standard deviation below the mean) through to high (one standard deviation above the mean), holding other variables fixed at their means. The relationship is computed for low innovativeness (one standard deviation below the mean), average innovativeness and high innovativeness (one standard deviation above the mean). The scale of the vertical axis (a unitless factor) does not have a meaningful interpretation and therefore values are not shown. 